\title{
The termination and aftermath of the Lomagundi-Jatuli carbon isotope excursions in the Paleoproterozoic Hutuo Group, North China
}

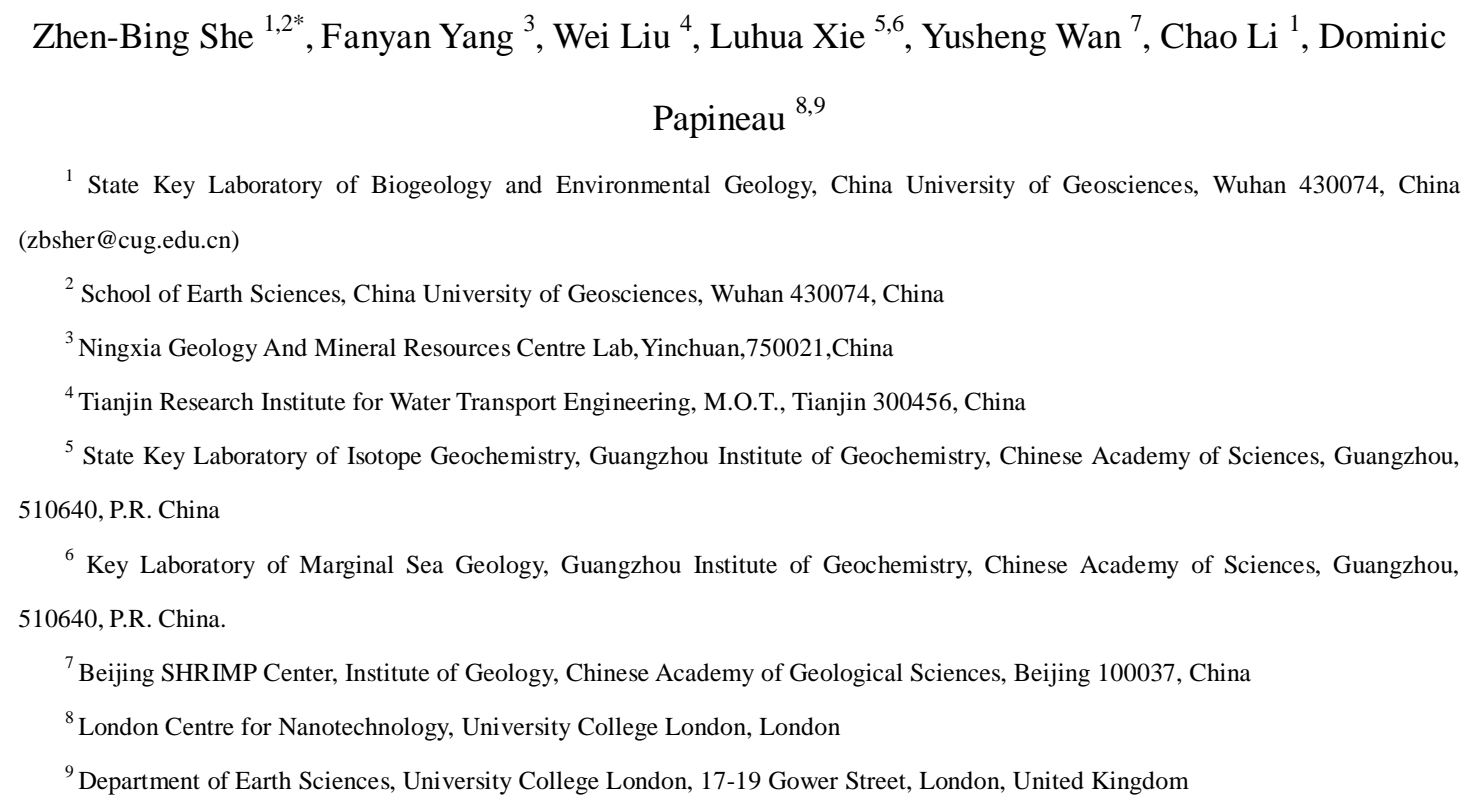

\section{Abstract}

The Lomagundi-Jatuli Event (LJE) is one of the largest and earliest positive carbon isotope excursions preserving $\delta^{13} \mathrm{C}_{\text {carb }}$ values between +5 and $+16 \%$ in Paleoproterozoic carbonates worldwide. However, the duration, amplitude and patterns of these excursions remain poorly constrained. The 2.14-1.83 Ga Hutuo Group in the North China Craton is a >10 $\mathrm{km}$ thick volcano-sedimentary sequence, including $>5 \mathrm{~km}$ thick well-preserved carbonates that were deposited in supra-tidal to sub-tidal environments. C-O isotopic and elemental analyses of 152 least altered samples of the carbonates revealed a three-stage $\delta^{13} \mathrm{C}$ evolution. It began with an exclusively positive $\delta^{13} \mathrm{C}_{\text {carb }}(+1.3$ to $+3.4 \%$ o) stage in the $\sim 2.1$ Ga carbonate in the Dashiling and Qingshicun Formations, followed by a transition from positive values to oscillating positive and negative values in $\sim 3000 \mathrm{~m}$ thick carbonates of the Wenshan, Hebiancun, Jianancun, and Daguandong Formations, and end with exclusively negative $\delta^{13} \mathrm{C}_{\text {carb }}$ values preserved in $>500 \mathrm{~m}$ thick dolostones of the Huaiyincun and Beidaxing 
1 Formations. It appears that much of the LJE, particularly those extremely positive $\delta^{13} \mathrm{C}_{\text {carb }}$

2 signals, was not recorded in the Hutuo carbonates. The exclusively positive $\delta^{13} \mathrm{C}_{\text {carb }}$ values

3 (+1.3 to $+3.4 \%$ ) preserved in the lower formations likely correspond to the end of the LJE,

4 whereas the subsequent two stages reflect the aftermath of the LJE and the onset of

5 Shunga-Francevillian Event (SFE). The present data point to an increased influence of oxygen

6 on the carbon cycle from the Doucun to the Dongye Subgroups and demonstrate that the

7 termination of the LJE in the North China Craton is nearly simultaneous with those in

8 Fennoscandia and South Africa.

9 Keywords Paleoproterozoic; Lomagundi-Jatuli Event; Hutuo Group; carbon isotope; carbonate

\section{Introduction}

The Paleoproterozoic is known as a period of profound perturbations in marine environments and biogeochemical cycles due to the Great Oxidation Event (GOE) (Melezhik et al., 2005a). Among these is the Lomagundi-Jatuli Event (LJE), one of the largest magnitude and earliest known positive carbonate carbon isotope excursions preserving $\delta^{13} \mathrm{C}_{\text {carb }}$ values between +5 and $+16 \%$ and even higher (Martin et al., 2013a, and references therein). The global nature of the LJE was supported by published C isotope data on Paleoproterozoic sequences from all continents with the exception of Antarctica (e.g., Maheshwari et al., 2010; Bekker et al., 2006; Karhu and Holland, 1996; Melezhik and Fallick, 1996; Baker and Fallick, 1989a; Schidlowski et al., 1976). Based on a compilation of age data from 22 sections in Fennoscandia, Norway, Scotland, Africa, North America and Australia, Karhu and Holland (1996) proposed a time span of 2.22 Ga to 2.06 Ga for the LJE. If true, the magnitude and extended duration of this carbon isotope anomaly suggest abnormally high rate of organic carbon burial and oxygen production which might have generated excess $\mathrm{O}_{2}$ between 12 and 22 times the present atmospheric $\mathrm{O}_{2}$ inventory (Karhu and Holland, 1996). The following negative shift in $\delta^{13} \mathrm{C}_{\text {carb }}$ up to $-14 \%$, i.e., the Shunga-Francevillian Event (SFE), has been attributed to the attainment of atmospheric and groundwater oxygen levels sufficient to 
oxidize the organic matter produced during the LJE (Kump et al., 2011).

Despite intensive studies, the duration, amplitude and the internal structures of the Lomagundi-Jatuli C isotope excursions remain poorly constrained due to incomplete preservation of the geological record combined with a limited availability of reliable carbonate-bearing sections with good age constraints (Melezhik et al., 2013; Maheshwari et al., 2010; Melezhik and Fallick, 2010). Based on the C-isotope data available at the time, Melezhik et al (1999a, b) suggested that the Paleoproterozoic positive excursions of $\delta^{13} \mathrm{C}_{\text {carb }}$ represent three positive shifts separated by returns to near zero values that occurred between 2.40 and $2.06 \mathrm{Ga}$. Other investigations, however, supported the view of a single sustained event (Martin et al., 2013a; Maheshwari et al., 2010; Bekker et al., 2003; Karhu and Holland, 1996). Alternatively, these excursions could have occurred locally and contemporaneously and thus do not represent global seawater, but rather a globally occurring phenomenon. Whether the terminations of the excursions occurred simultaneously all over the world also remains to be answered, because well constrained chronological framework has been established in relatively few successions in Fennoscandia and South Africa (Martin et al., 2013a). On the basis of the review on published chronological data, Martin et al (2013a) proposed a maximum permitted range between $2306 \pm 9$ and $2057 \pm 1$ Ma and a minimum permitted range between $2221 \pm 5$ and $2106 \pm 8$ Ma for the LJE. Therefore, each new section containing a substantial carbonate record represents a valuable addition, and might improve our current understanding of the local and regional of the LJE.

The North China Craton (NCC) is an Early Precambrian continental block with well exposed Paleoproterozoic sequences, including the Hutuo Group in the Wutai area of Shanxi Province, the Songshan Group in northern Henan Province, and the Liaohe Group in eastern Liaoning Province. During the last two decades or so, attempts have been made to locate positive $\delta^{13} \mathrm{C}_{\text {carb }}$ excursions in these successions correspond to the global excursions (Lai et al., 2012; Kong et al., 2011; Tang et al., 2011; Zhong and Ma, 1997). Available data have documented the presence of carbonates with $\delta^{13} \mathrm{C}$ up to 3.5\%o (Zhong and Ma, 1997) or 3.2\%o (Kong et al., 2011) in the Hutuo Group, to 4.2\%o in the Songshan Group (Lai et al., 2012), and to 5.9\%o in the Liaohe Group (Tang et al., 2011). Some of these studies, however, are based on problematic chronological framework (Fig. 1; Kong et al., 2011; Zhong and Ma, 1997) or 
1 provide only limited data (Lai et al., 2012; Tang et al., 2011) which dampen the correlation

2 with global events. In this study we conducted detailed study of the geology of the Hutuo

3 Group in the Wutai area and obtained C-O isotopic and elemental composition data for 152

4 carbonate samples. Combined with newly published high-precision chronological data, this

5 documents transition from persistently positive $\delta^{13} \mathrm{C}_{\text {carb }}$ to more variable positive and negative

6 values in 2.1-1.9 Ga carbonates, which signals the termination of the LJE in the NCC.

\section{Geological settings}

The NCC refers to the Chinese part of the Sino-Korean Craton. It covers an approximately triangular area of ca. 1,500,000 $\mathrm{km}^{2}$ and consists of Eoarchean to Paleoproterozoic basement that underlies Mesoproterozoic to Cenozoic unmetamorphosed covers (Fig. 1). Zhao et al. (1999, 2005) divided the NCC into the Eastern and Western Blocks and the Trans-North China Orogen sandwiched in between.

Paleoproterozoic volcano-sedimentary successions are widespread in the NCC, which include, but are not limited to, the Hutuo Group in the Wutai area, the Liaohe Group in the eastern Liaoning Province and the Songshan Group in northern Henan Province (Fig. 2). These might have deposited in a suite of Paleoproterozoic rift systems which started with the eruption of continental flood basalt and bimodal volcanics (Kusky and Li, 2003). This is supported by the geochemistry of the metabasalts in the lower part of the Hutuo Group which indicate eruption in a intra-plate rift setting (Du et al., 2009) and by the structural geology and regional stratigraphy (Guo et al., 2011). Other researches, however, argue that the Hutuo Group represents the sedimentary record of the foreland basin developed in response to the collision of the Western and Eastern Blocks at ca. 1.85 Ga (e.g., Liu et al., 2011).

In the Wutai area, Neoarchean to Paleoproterozoic basement rocks are well exposed. The 2.55-2.50 Ga Wutai Group consists mainly of mafic and felsic volcanic rocks interbedded with minor banded iron formations that is metamorphosed to the greenschist to amphibolite facies, whereas the Paleoproterozoic Hutuo Group is dominated by clastic rocks and carbonates which have undergone a lower greenschist facies metamorphism with the mineral association of metapelites in the Hutuo Group being chlorite + muscovite + quartz \pm epidote \pm albite (Bai, 1986). 

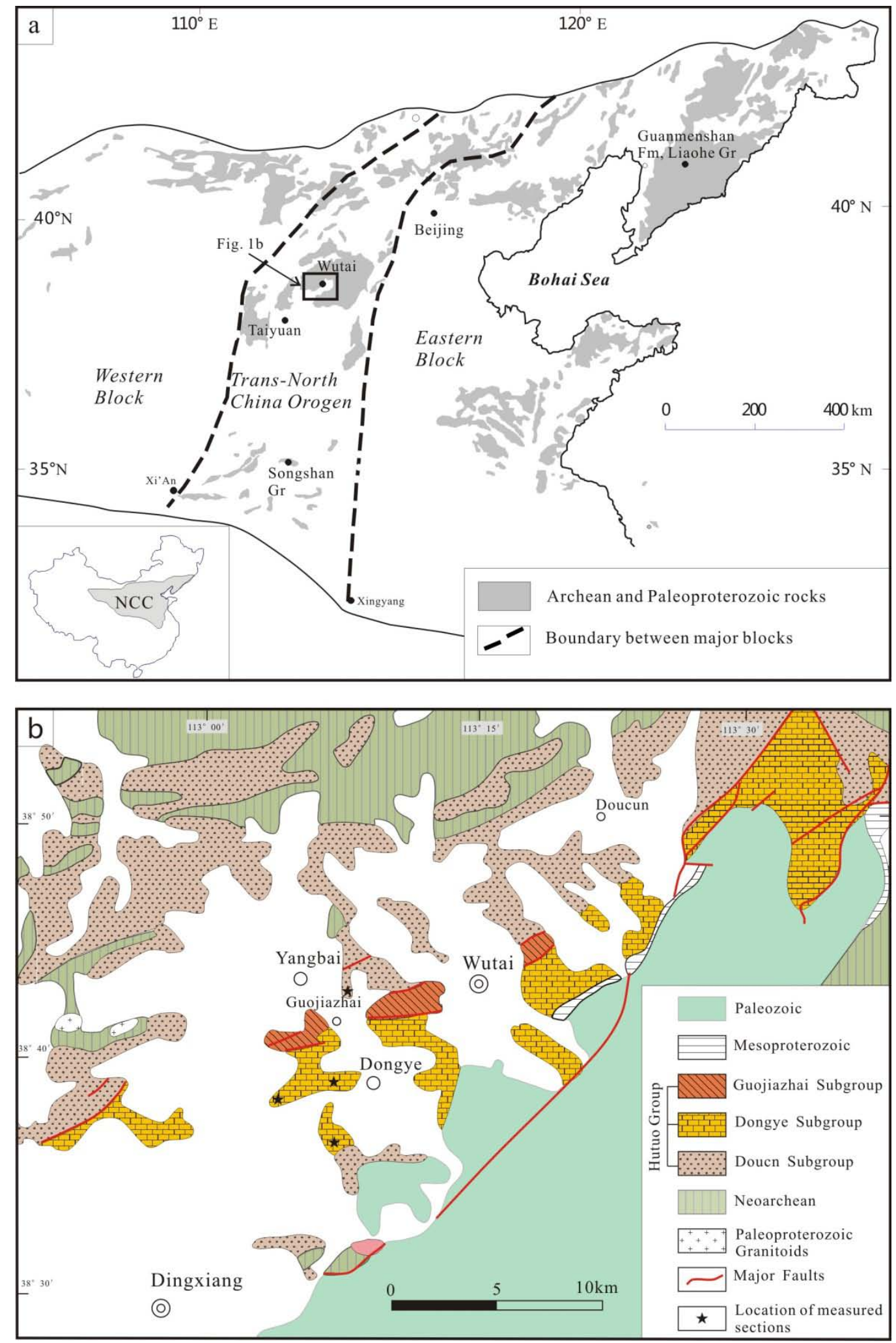

Figure 1 (a) Tectonic divisions of the North China Craton highlighting exposed Archean and Paleoproterozoic rocks (modified after Zhao et al., 1999). (b) Simplified geological map of the Wutai area (modified after Bai, 1986).

The Hutuo Group represents the latest sedimentary record of the Early Precambrian in the 
1 Wutai area, unconformably underlying and overlying the Mesoproterozoic Changcheng System

2 and the Neoarchean Wutai Group, respectively. The total thickness is estimated to be $>10,000 \mathrm{~m}$.

3 The Hutuo Group is generally divided into three subgroups, i.e., the lower Doucun Subgroup, the

4 middle Dongye Subgroup and the upper Guojiazhai Subgroup (Fig. 2) (Bai, 1986), although other

5 researchers have proposed that the former two subgroups might represent contemporaneous 6 sedimentation at different environments (Miao et al., 1999). Possible sedimentary hiatus between

7 the Doucun and Dongye Subgroups is characterized by a paleo-weathering crust developed on the 8 topmost metabasalts of the Qingshicun Formation (Bai, 1986). The stark contrast and sharp 9 contact between the carbonates of the Dongye Subgroup and the red siliciclastic rocks of the 10 Guojiazhai Subgroup marks a significant sedimentary hiatus bounded by an unconformity.

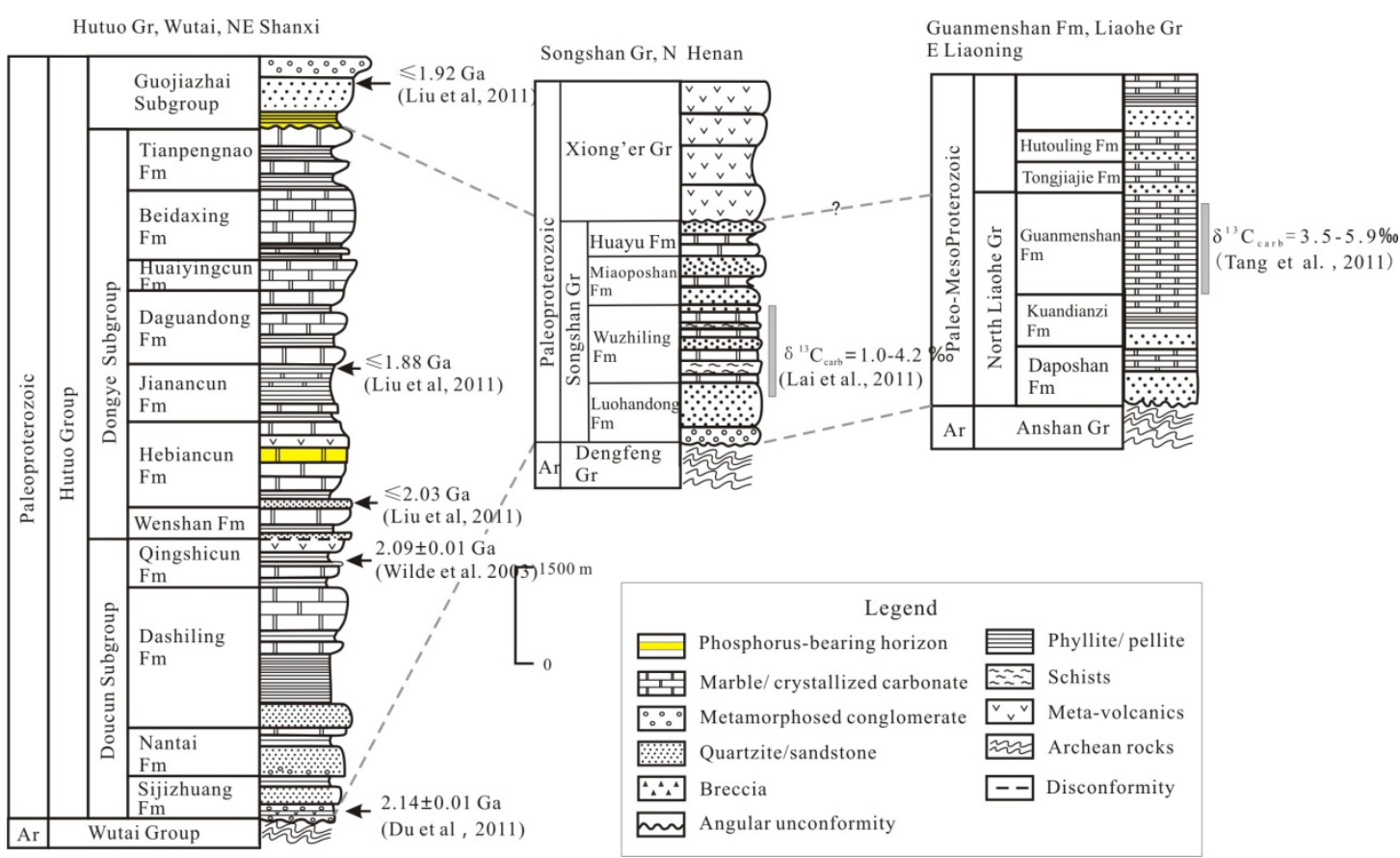

Figure 2 Generalized stratigraphic column of the Hutuo Group with correlation to Paleoproterozoic successions in

N Henan (Lai et al., 2011) and E Liaoning provinces (Tang et al., 2011). Previously published age dates and C isotope data are shown.

The three subgroups are further subdivided into 14 formations according to their lithological assemblages (Bai, 1986). The Doucun Subgroup, which consists of the Sijizhuang, Nantai, Dashiling and Qingshicun Formations, is a fining-upward succession with a basal conglomerate associated with volcanic rocks (the Sijizhuang Formation), that represent the sedimentary record of the inception of a rift basin (Kusky and Li, 2003; Bai, 1986) or a graben-related environment 
1 (Miao et al., 1999). The conglomerates grade upward to quartzites and phyllites, then to phyllites interbedded with dolostones, with occurrence of thickly bedded dolostones at the top. The Dongye Subgroup is subdivided into the Wenshan, Hebiancun, Jianancun, Daguandong, Huaiyincun and Beidaxing, and Tianpengnao Formations. It comprises a carbonate-dominated sequence with minor intercalations of metapelite and metabasalt. Stromatolites with various morphologies are present in all the formations excepting the Huaiyincun Formation. This part corresponds to the transgression maximum. Phosphorus-bearing horizons have been reported from the Hebiancun Formation (Dongye, 1989). The Guojiazhai Subgroup is a non-marine molasse deposit unconformably overlying carbonates of the Dongye Subgroup (Bai, 1986). It comprises an upward-coarsening sequence, which is > 900 m-thick in the NNW and rapidly pinches out in the SSE (Miao et al., 1999). A second phosphorus-bearing horizon has been reported from the basal sandstones and breccias of the sequence (Dongye, 1989), which is correlated to "Dongjiao Type" phosphorous deposit that resides in equivalent siliciclastic sequence in adjacent Hebei Province (Zhao, 1982).

Conventionally, the Hutuo Group was thought to be deposited between 2.45-2.37 Ga (Wang, 1997; Wu et al., 1986) or 2.37-1.90 Ga (Bai, 1986). Recently published high-precision geochronological data, however, have demonstrated that the Hutuo Group is significantly younger than previously thought and probably deposited between 2.14 and 1.83 Ga (Du et al., 2013; Du et al., 2011; Liu et al., 2011; Du et al., 2010; Wan et al., 2010; Wilde et al., 2004). SHRIMP zircon $\mathrm{U}-\mathrm{Pb}$ dating of a metamorphosed basaltic andesite in the Sijizhuang Formation of the Hutuo Group yielded a mean weighted ${ }^{207} \mathrm{~Pb} /{ }^{206} \mathrm{~Pb}$ age of $2140 \pm 14 \mathrm{Ma}$ (Du et al., 2010), constraining the lower limit of its depositional age. Wilde et al (2004) reported a SHRIMP zircon ${ }^{207} \mathrm{~Pb} /{ }^{206} \mathrm{~Pb}$ age

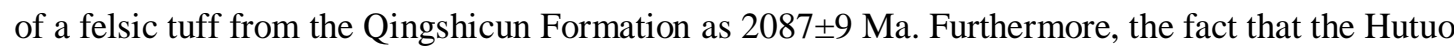
Group is intruded by 1.83-1.77 Ga mafic dykes suggests $1.83 \mathrm{Ga}$ as the upper limit of the depositional age (Guo et al., 2011; Hou et al., 2005). Liu et al (2011) reported detrital zircons as young as $1.88 \mathrm{Ga}$ from the Jianancun Formation, which further constrains that the Daguandong, Huaiyincun, Beidaxing and Tianpengnao Formations were deposited during a relatively short period between 1.88 and $1.83 \mathrm{Ga}$. 


\section{Sedimentary structures and depositional environments}

The Hutuo Group retains an archive of diverse primary sedimentary structures (Fig. 3). In the lowermost part of the Hutuo Group which is dominated by clastic rocks, cross bedding (Fig. 3a), ripple marks (Fig. 3b), flaser bedding and parallel bedding are commonly observed, whereas graded bedding and convolute bedding (Fig. 3d) locally occur. Casts and pseudomorphs of halite and desiccation cracks were also reported from the Dashiling Formation (Bai, 1986). These point to deposition mainly in peritidal environments, except for intermittent periods of turbidites deposition probably related the active rifting of the Hutuo basin (Bai, 1986).

The $>5000 \mathrm{~m}$ thick carbonate-dominated proportion of the Hutuo Group, however, is characterized by various stromatolite morphotypes that range from centimeter-size digitate forms to large bioherms up to $2 \mathrm{~m}$ in diameter (Fig. 3e-h), along with disturbed bedding and intraclastic structures (Fig. 3c). Stromatolite diversity in the Hutuo Group has been previously studied in detail (Zhu and Chen, 1992; Zhu, 1982), and 51 groups and 96 morphtypes has been recognized (Bai, 1986). Closely-packed decimeter-size columns of stromatolites are also observed (Fig. 3i), indicating accelerated growth of photosynthetic microbial communities. Oölites, low-angle cross bedding and tidal bedding have also been reported (Bai, 1986). Early diagenetic silicification is common in the Hutuo carbonates, usually forming high relief chert layers intercalated with low relief pure dolostones and helps to preserve primary sedimentary structures (Fig. 3j). In general, these sedimentary structures suggest that the Hutuo carbonates were deposited in supra-tidal to sub-tidal environments during the formation of a carbonate ramp.

\section{Samples and methods}

Over 300 samples were collected at the four investigated sections (Fig. 1b). Best available samples were selected from fresh outcrops lacking shear, foliation, or fractures although secondary veinlets and silicification could not be completely avoided. Prior to geochemical analyses, each of the samples was petrographically characterized with naked eyes and optical microscope. Among these, 152 least altered carbonates were analyzed for $\mathrm{C}$ and $\mathrm{O}$ isotope and elemental concentrations. 

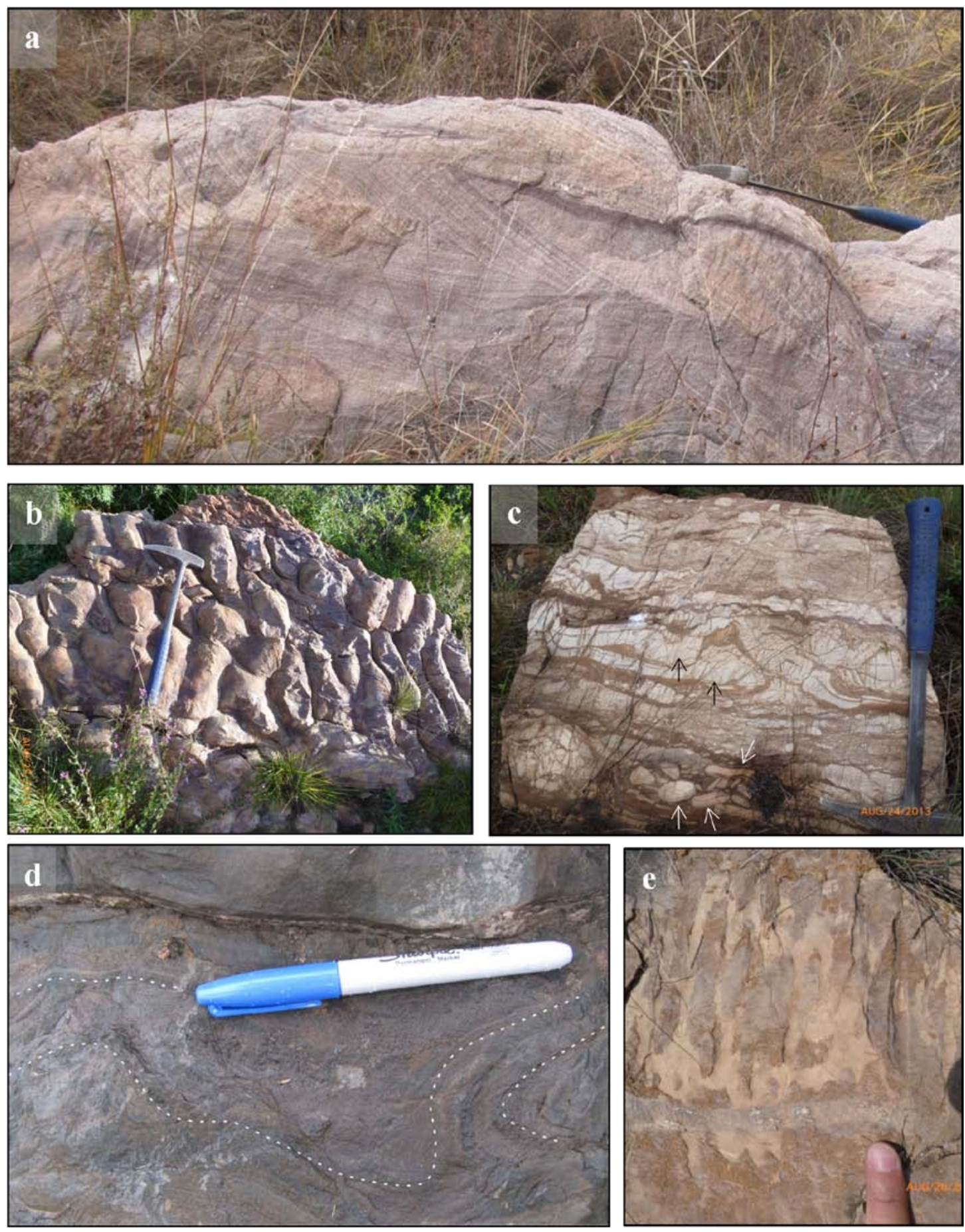

Figure 3 Sedimentary structures. (a) Herringbone cross-bedding, Wenshan Fm. (b) Ripple marks, Wenshan Fm. (c)

Disturbed beds (black arrows), rounded intraclasts and flat pebbles (white arrows), Hebiancun Fm. (d) Convolute

4 bedding, Qingshicun Fm. (e) Digitate stromatolite, Jianancun Fm. (f) Stromatolite bioherms, Jianancun Fm. (g)

5 Stromatolite bioherms, Dashiling Fm. (h) Purple-colored wavy-Conical stromatolites, Wenshan Fm. (i) Oblique

6 section of tightly-packed stromatolites, Daguandong Fm. (j) Cherty dolostone with alternating purplish chert layers

7 (ch) and white dolomicrite layers (dol) indicating silicification during very early diagenetic stage, Hebiancun Fm.

8 Hammers are $40 \mathrm{~cm}$ long, and marker pen is $14 \mathrm{~cm}$ long. 

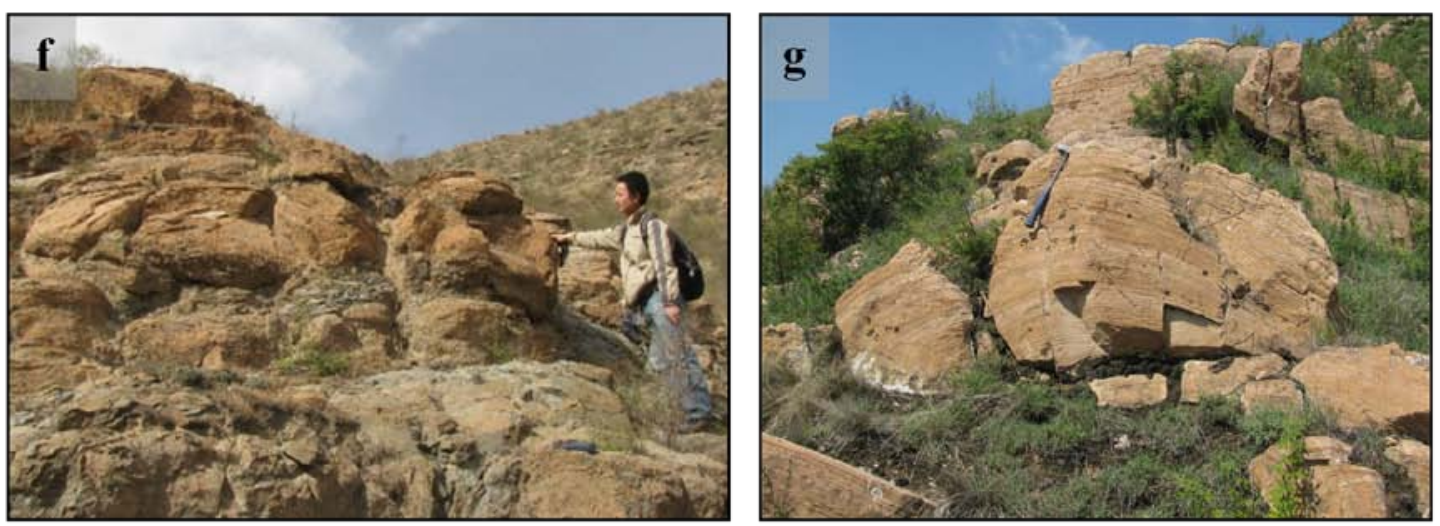

2
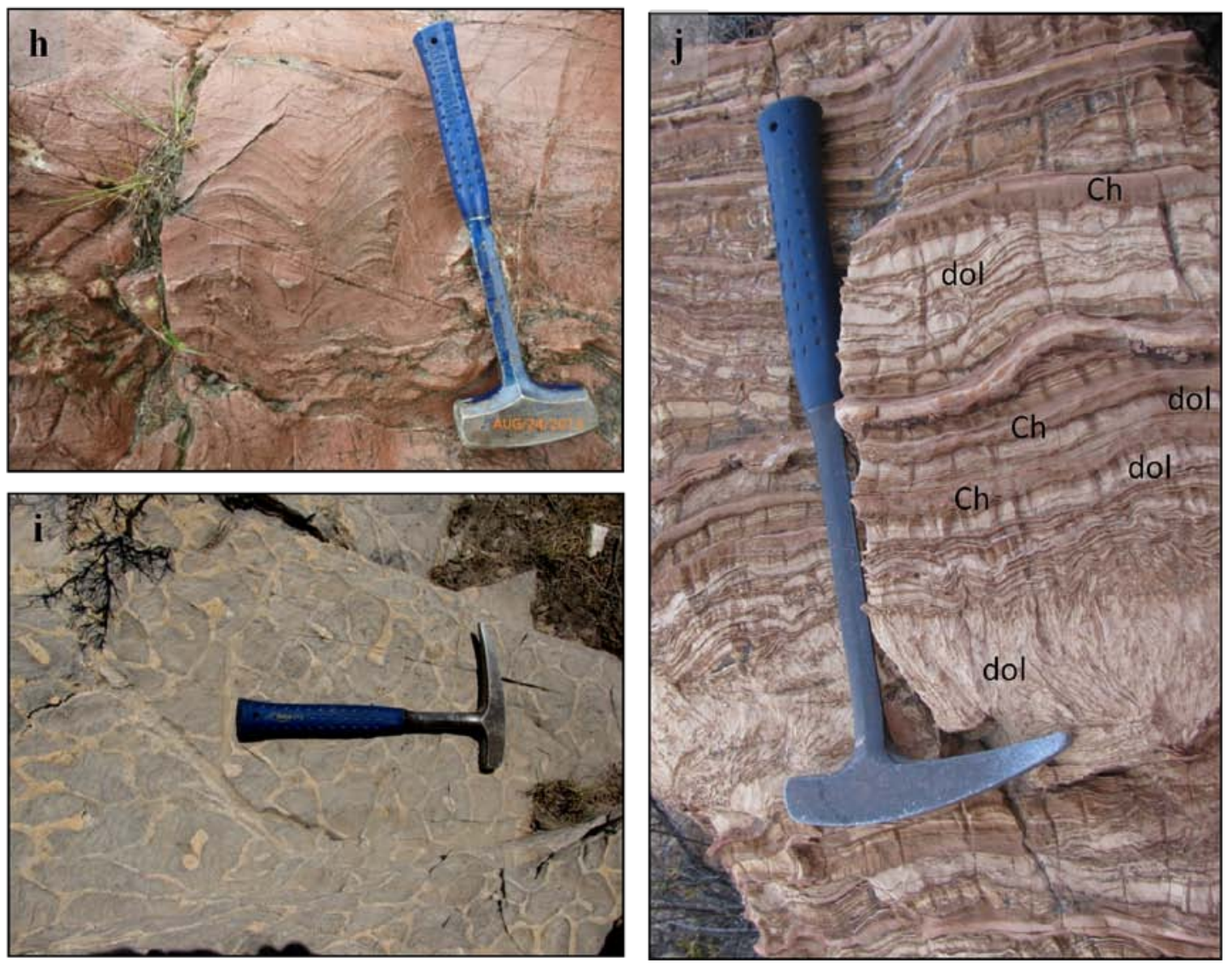

Figure 3 continued.

Rock samples were trimmed off weathered surfaces and crushed into pieces less than $1 \mathrm{~cm}$ in diameter. Rock chips devoid of veinlets or fractures were hand-picked. They were then cleaned by ultrasonication, repeatedly rinsed with distilled water, dried, and powdered.

Analyses of elemental composition were conducted with a PerkinElmer Elan9000 ICP-MS at ALS Chemex (Guangzhou) co ltd. The detection limit is $0.1 \%$ for Mg, Fe and Ca, 5 ppm for Mn and $0.2 \mathrm{ppm}$ for Sr. Oxygen and carbon isotopes were determined with a Finningan MAT-251 mass spectrometer at the State Key Laboratory of Geological Processes and Mineral Resources, China University of Geosciences (Wuhan), or with an Isoprime 100 mass spectrometer at the State 
key Laboratory of isotope Geochemistry, Guangzhou Institute of Geochemistry, Chinese Academy of Science. Carbon and oxygen isotopic compositions were measured on $\mathrm{CO}_{2}$ liberated from powdered carbonates using 100\% phosphoric acid. Multiple measurements of standards (NBS19, IAEA-CO-8, GBW04405 and GBW04406) yielded analytical precision better than $0.15 \%$ for both $\mathrm{C}$ and $\mathrm{O}$ isotopes. The $\delta^{13} \mathrm{C}_{\text {carb }}$ and $\delta^{18} \mathrm{O}_{\text {carb }}$ data are reported in standard per mil (\%) relative to V-PDB. $\delta^{18} \mathrm{O}_{\mathrm{V}-\text { SMOW }}$ was calculated according to $\delta^{18} \mathrm{O}_{\mathrm{V}-\mathrm{SMOW}}=1.03086 \times \delta{ }^{18} \mathrm{O}_{\mathrm{V}-\mathrm{PDB}}+30.86$ (Nafi et al., 2004).

In addition to the whole-rock analyses, 28 micro-drilled samples were also analyzed for $\mathrm{C}$ isotopes. Carbonates containing no carbonaceous material were selected based on optical microscopy. The slabs were polished with silicon carbide paper and then cleaned by ultrasonication, rinsed with deionized distilled water and dried. The least altered (lacking veins, discoloration, weathering rinds, and silification) and finest -grained portions of the slabs were micro-drilled with a $2.0 \mathrm{~mm}$ diameter $\mathrm{SiC}$ drill bit to obtain pristine rock powders. For carbon isotope analyses, 1.6 - $5.8 \mathrm{mg}$ of powders were weighed in $\mathrm{Ag}$ capsules pre-muffled at $600{ }^{\circ} \mathrm{C}$ for 2 hours. Carbon isotope analyses were performed at Boston College with an ECS 4010 elemental analyzer (EA) linked to a ThermoFisher Delta V Plus IRMS through a Conflo IV interface as previously described (Papineau et al., 2010). $\delta^{13} \mathrm{C}$ values are reported as per mil (\%) deviation from V-PDB. External reproducibility determined by multiple measurements of NBS22 standards was better than $0.1 \% 0(1 \sigma, \mathrm{n}=27)$, respectively.

\section{Results}

\subsection{Petrographic characterization}

Petrographic observation were made on hand specimens, polished rock slabs and thin sections to evaluate the effects of post-depositional processes on primary textures. Most of the samples retained their original textures to variable extents, consistent with the low degree of metamorphism. In either the massive dolostones (Fig. 4a and b) or the laminated (stromatolitic) dolostones (Fig. 4c-f), crystal sizes are generally $<15 \mu \mathrm{m}$ (Fig. $4 \mathrm{~b}$ and d). This, along with the preservation of organic-rich clots and laminae (Fig. 4c-f), show that the original textures and mineralogy were commonly unaltered and the samples likely preserve primary carbon isotope 
2 in most cases and are almost impossible to avoid during preparation of bulk-rock powders, are 3 present in many samples (Fig. 4a and e). In order to assess the effect of these veinlets on the C 4 isotope ratio, as mentioned above, $\delta^{13} \mathrm{C}_{\text {carb }}$ of samples micro-drilled from polished rock slabs were 5 also obtained and compared with those of bulk-rock powders from the same rocks.
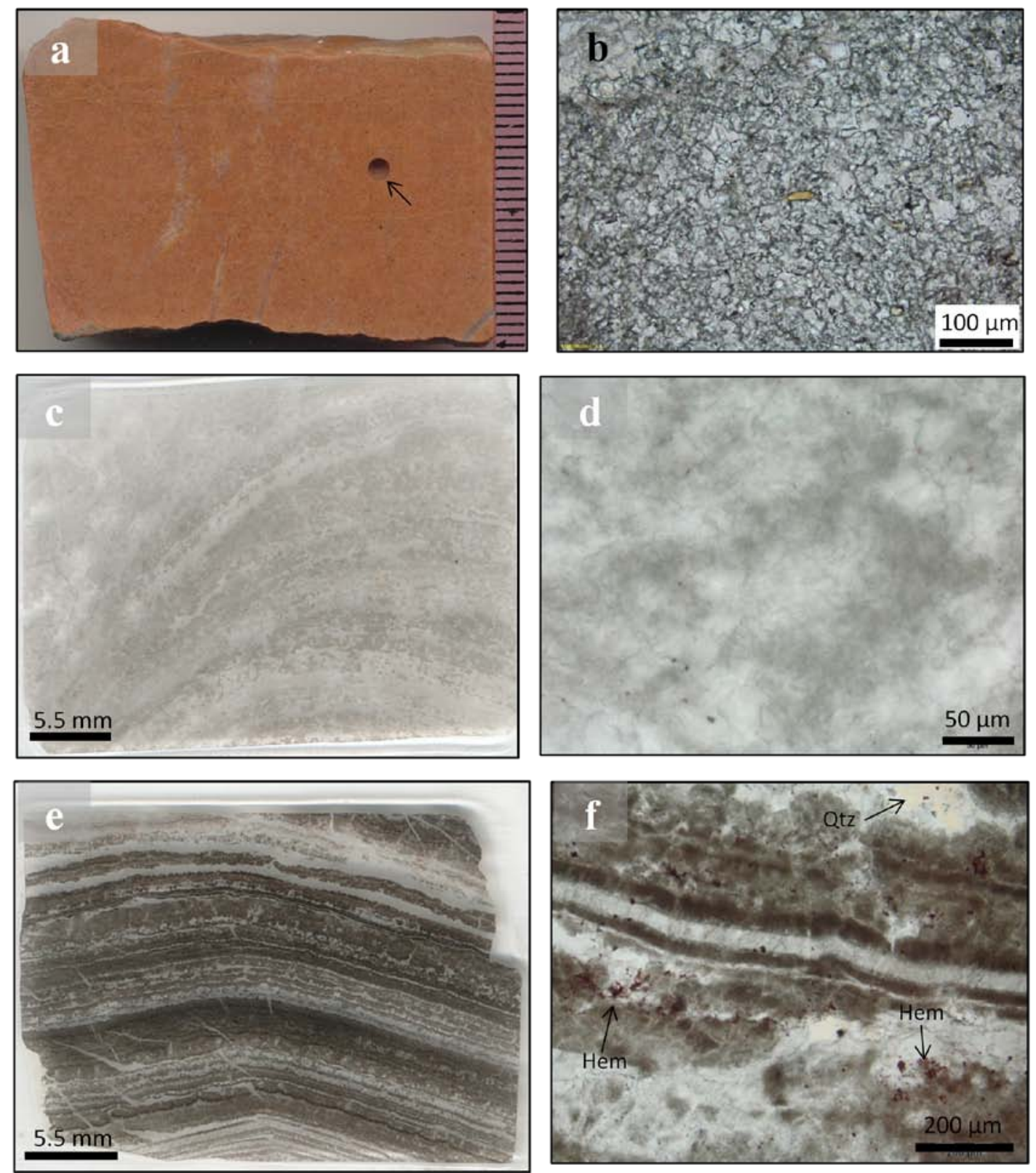

Figure 4 Petrographic features of the Hutuo carbonates. (a) Slab of an orange-colored massive dolostone micro-drilled for C isotope analysis, arrow showing the drill pit. (b) Pure microcrystalline dolostone with crystals generally smaller than $15 \mu \mathrm{m}$. (c) Primary laminae in stromatolitic dolostone. (d) Magnified view of (c) showing dolomite microcrystals and clots of carbonaceous material. (e) Alternated dark organic-rich and transparent dolomite laminae in a stromatolite. (f) Magnified view of (e) showing the dark organic-rich layers and clots. Note 


\subsection{Elemental concentrations}

Ca and Mg contents of the Hutuo dolostones vary from 6.6 to $21.7 \%$ and from 4.1 to $13.7 \%$ ( $\mathrm{n}=152$ ), respectively. $\mathrm{Mg} / \mathrm{Ca}$ ratios, however, fall in a restricted range between 0.58 and 0.63 . Cherty dolostones have lower Ca (5.32 - 21.00\%) and Mg (3.09 - 11.55\%) contents and slightly more variable $\mathrm{Mg} / \mathrm{Ca}$ ratios (0.58-0.65). $\mathrm{Mg} / \mathrm{Ca}$ ratios of the limestones are generally lower than 0.1 .

The Hutuo dolostones contain variable amounts of Fe (0.02-3.35 \%, $0.63 \%$ on average), Mn (50 - 3610 ppm, 638.6 ppm on average) and Sr (5.5 - 329 ppm, 57.8 ppm on average). The cherty dolostones have generally lower Fe (0.13 - 0.85\%, 0.47\% on average) and Mn (87 - 901 ppm, 371 ppm on average) but higher Sr (14.4 - 321 ppm, 91.5 ppm on average) abundances. The limestones are characterized by very high abundance of Sr ranging between 142.5 and 2050 ppm, with an average of $589.5 \mathrm{ppm}$. Their Fe (0.08 - 2.97\%) and Mn (35 - 4180 ppm) contents are similar to those of dolostones. $\mathrm{Mn} / \mathrm{Sr}$ ratios of the dolostones vary from 1.6 to 127.3 , with an average of 16.6, whereas those of the cherty dolostones (14.4 - 155.0, 9.7 on average) and limestones (0.07 - 21.1 , 10.2 on average) are slightly lower overall.

\subsection{C- and O-isotopes of carbonates}

$\delta^{13} \mathrm{C}_{\text {carb }}$ values obtained from whole-rock samples range between -5.2 and $+3.4 \%$ o $(0.5 \%$ on average, $\mathrm{n}=152)$, whereas the $\delta^{18} \mathrm{O}_{\text {carb }}$ varies from to -16.3 to $-2.7 \%$ V-PDB (-8.9\% on average) (Table 1). The heaviest $\delta^{13} \mathrm{C}_{\text {carb }}(+3.4 \%$ ) came from the Dashiling Formation, whereas the lightest $\delta^{13} \mathrm{C}_{\text {carb }}(-5.2 \%)$ were obtained at the top of the Hebiancun Formation. The Dashiling Formation, which represents the lowermost portion of the studied carbonate unit in the Hutuo Group, yielded exclusively positive and consistent $\delta^{13} \mathrm{C}_{\text {carb }}$ values between +1.3 to $+3.4 \%$ o ( $+2.4 \%$ on average). Two samples from the Qingshicun Formation gave $\delta^{13} \mathrm{C}_{\text {carb }}$ values between 0.3 and $0.7 \%$. The overlying Wenshan Formation are characterized by slightly positive $\delta^{13} \mathrm{C}_{\text {carb }}$ from +0.2 to $+1.8 \%$. The Hebiancun Formation, however, shows a general trend of decrease in $\delta^{13} \mathrm{C}_{\text {carb }}$ from +2.7 to -5.2\%. Further up-section, the Jianancun Formation display variable $\delta^{13} \mathrm{C}$ values between -3.6 and 
$1+1.6 \%$. $\delta^{13} \mathrm{C}_{\text {carb }}$ of the Daguandong Formation show slight fluctuation below and above $0 \%$. The

2 Huaiyincun and Beidaxing Formations are characterized by a transition from positive to negative

$3 \quad \delta^{13} \mathrm{C}_{\text {carb }}$ values generally lighter than $-2 \%$.

$4 \quad$ Twenty-eight micro-drilled samples yielded results consistent with the whole rock data (Table

$5 \quad 1$ and Fig. $6 \mathrm{~A}) . \delta^{13} \mathrm{C}$ of twenty six samples from the Dashiling Formation range between +1.2 to

$6 \quad+3.1 \%$, with an average of $+2.4 \%$, which are almost identical to those of the whole rock $\delta^{13} \mathrm{C}_{\text {carb }}$.

7 Two samples from the Daguandong Formation gave $\delta^{13} \mathrm{C}$ values of $0.4 \%$ and $-1.7 \%$, similar to

8 those obtained by bulk rock analysis ( $0.9 \%$ and $-1.3 \%$, respectively).

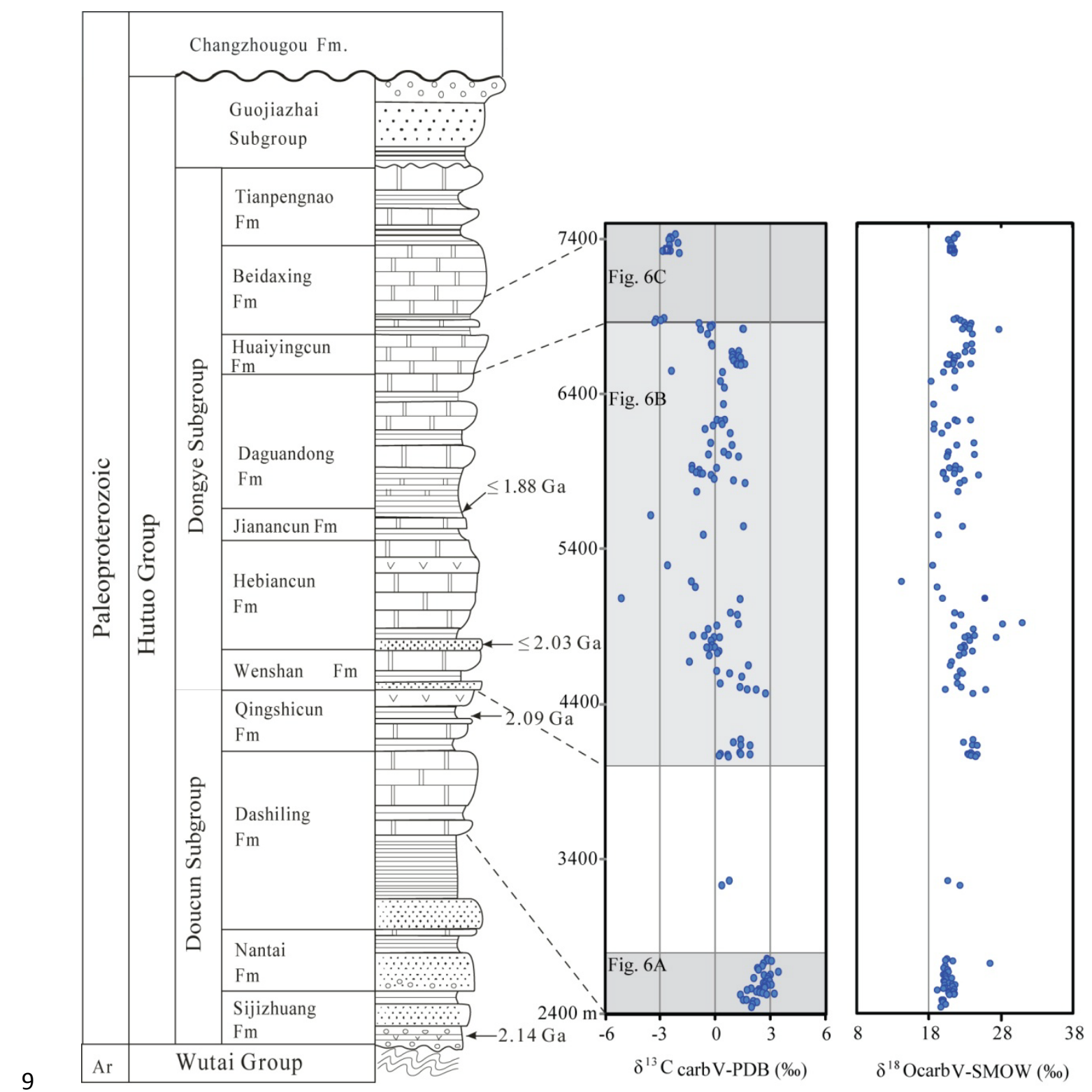

10 Figure 5 Stratigraphic variation of $\delta^{13} \mathrm{C}, \delta^{18} \mathrm{O}$ and $\mathrm{Mn} / \mathrm{Sr}$ ratios of the Hutuo Group. Three stages of the $\delta^{13} \mathrm{C}$ curve

(A, B and C) are shown in detail in Fig. 6. 


\section{Discussion}

2 5.1 Impact of post-depositional processes on $\mathrm{C}$ and $\mathrm{O}$ isotope composition

3

Depending on post-depositional process such as metamorphism, original carbon and oxygen isotope compositions of carbonate rocks could either be altered (e.g., Lewis et al., 1998; Bickle et al., 1997, 1995) or retained even under amphibolite-facies conditions (e.g., Melezhik et al., 2001; Boulvais et al., 1998; Baker and Fallick, 1989a, b). Diagenesis and metamorphism tend to result in a decrease in both $\delta^{13} \mathrm{C}_{\text {carb }}$ and $\delta^{18} \mathrm{O}_{\text {carb }}$ (Melezhik and Fallick, 2010; Bekker et al., 2005; Melezhik et al., 1999b; Guerrera et al., 1997). However, carbon isotope composition of most of the bulk rock samples are unlikely to change signficantly during non-organic diagenesis because carbon content in carbonates is vastly greater than that in pore-water reservoir and because the fractionation between calcium carbonate and water is relatively small at near-surface temperatures (Emrich et al., 1970). A detailed study on Paleoproterozoic ${ }^{13}$ C-rich carbonates by Melezhik and Fallick (2003) has shown that non-organic diagenesis produced a very little effect on primary isotopic values. Oxygen isotope, on the contrary, are often subject to secondary alteration (e.g., Hudson, 1977).
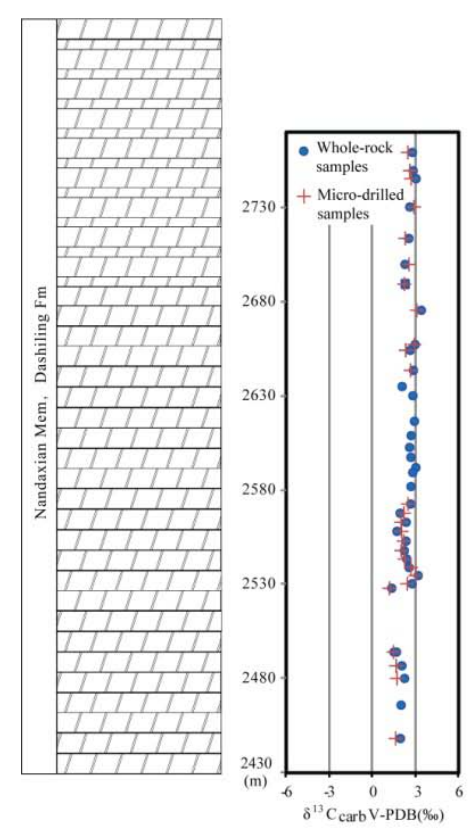
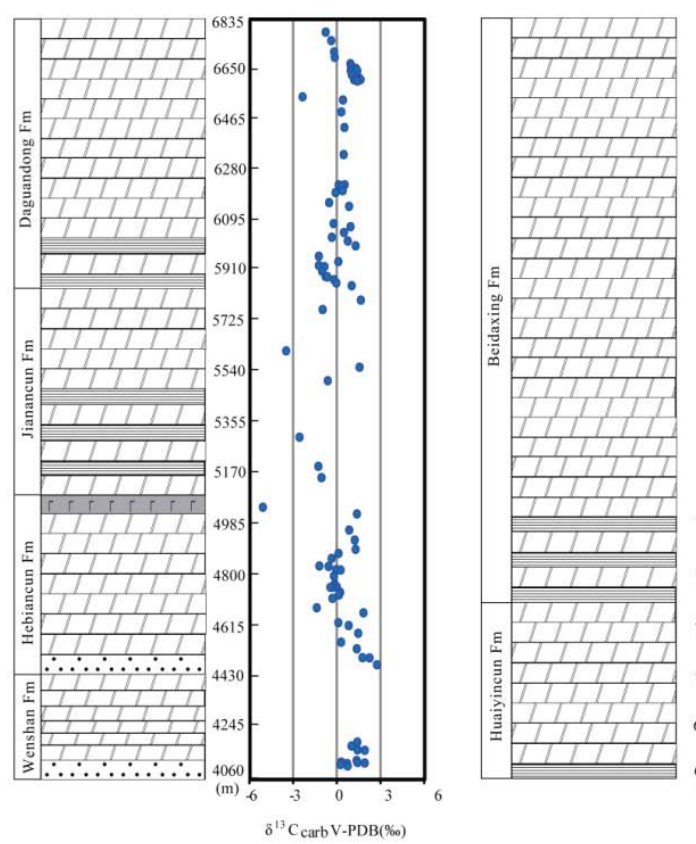

Figure $6 \delta^{13} \mathrm{C}$ curves of the lower, middle and upper part of the Hutuo carbonates.

Various parameters, including $\mathrm{Mn} / \mathrm{Sr}, \mathrm{Fe} / \mathrm{Sr}, \mathrm{Ca} / \mathrm{Sr}$ and $\mathrm{Rb} / \mathrm{Sr}$ ratios, and carbon and oxygen isotopes, are used as criteria for detecting the least altered carbon and oxygen systems. 
1 Co-variation of $\delta^{13} \mathrm{C}$ and $\delta^{18} \mathrm{O}$ values is generally regarded as an indicator for diagenetic (e.g., 2 Bathurst, 1972) or metamorphic (e.g., Valley, 1986) resetting. A complete resetting of $\delta^{13} \mathrm{C}$ and $3 \delta^{18} \mathrm{O}$ by diagenesis or metamorphism results in a non-linear $\delta^{13} \mathrm{C}-\delta^{18} \mathrm{O}$ alteration trend (e.g., 4 Melezhik et al., 2005b; Jacobsen and Kaufman, 1999). Influence of meteoric diagenesis can be 5 estimated by $\mathrm{Mn} / \mathrm{Sr}$ ratios, because carbonates affected by meteoric fluids are usually depleted in 6 Sr and enriched in Mn (Kaufman and Knoll, 1995; Veizer, 1983). Mn/Sr ratios greater than 10 7 (Kaufman and Knoll, 1995) or 6 (Melezhik et al., 1999b) are considered to imply significant 8 post-depositional alteration. However, application of this criteria is undermined by the fact that 9 dolostone generally contains less $\mathrm{Sr}$ and more $\mathrm{Mn}$ and hence have higher $\mathrm{Mn} / \mathrm{Sr}$ ratio than 10 limestone (e.g., Gaucher et al., 2007).
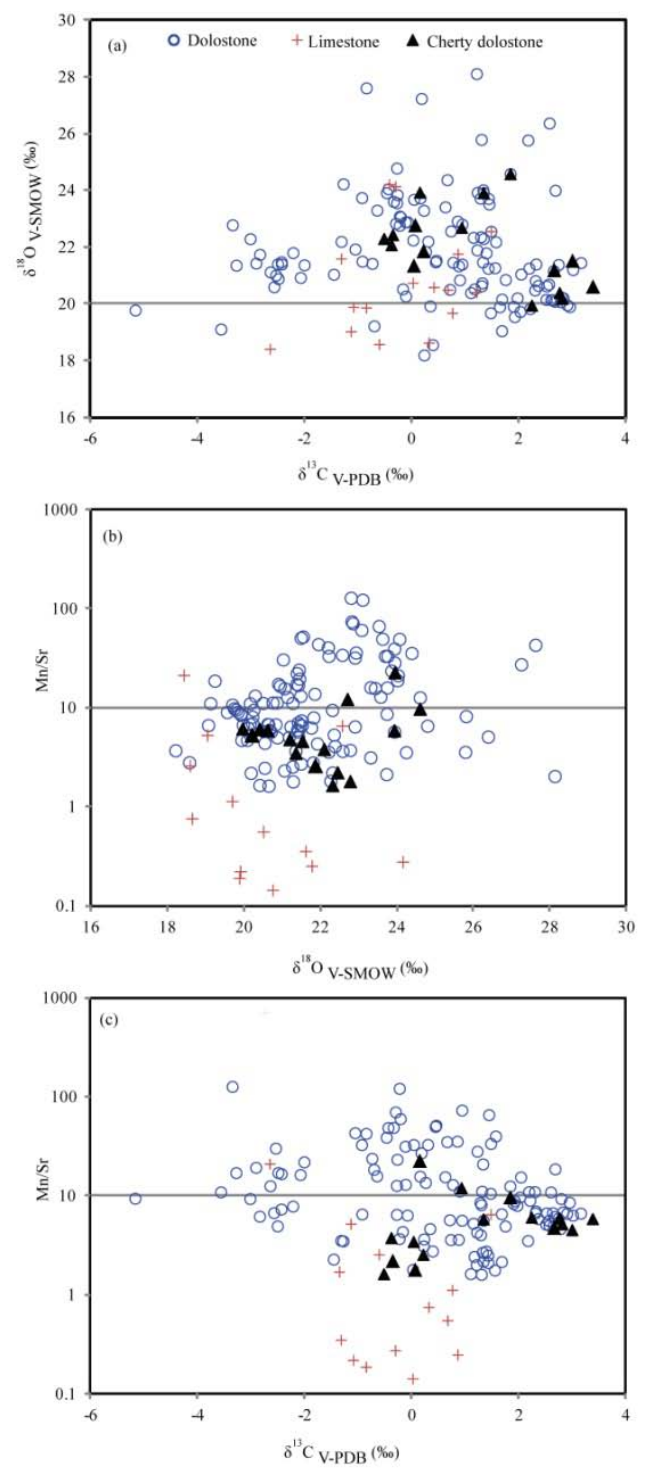

Figure 7 Cross-plots illustrating post-sedimentary alteration of the carbonates. 
As shown in Fig. 7a, $\delta^{13} \mathrm{C}$ and $\delta^{18} \mathrm{O}$ values of the Hutuo carbonates do not show any evident

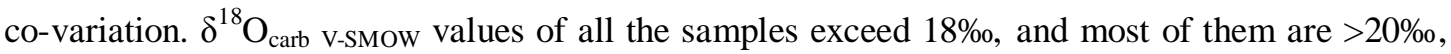
suggesting that the $\mathrm{C}-\mathrm{O}$ isotopes are largely unaffected by post-sedimentary processes. The limestones have significantly lower $\mathrm{Mn} / \mathrm{Sr}$ ratio compared with the dolostones and cherty dolostones (Fig. 7b), consistent with previous studies (Gaucher et al., 2007). The slightly positive correlation between $\mathrm{Mn} / \mathrm{Sr}$ and $\delta^{18} \mathrm{O}_{\text {carb }}$ of the dolostones argues against influence of meteoric diagenesis. As an alteration proxy proven to be useful for limestones, $\mathrm{Mn} / \mathrm{Sr}$ ratio should not be applied without further considerations to dolostones, because chemistry and structure of dolomite allows less amounts of Sr but far more Mn and Fe to be incorporated into the crystal lattice (Kah et al., 1999; Deer et al., 1992). Therefore, the high Mn/Sr ratios in the Hutuo dolostones probably resulted from high seawater Mn concentrations (Maheshwari et al., 2010) rather than from diagenetic or metamorphic alteration. The limestones display significantly lower $\mathrm{Mn} / \mathrm{Sr}$ ratios and somewhat lighter $\delta^{18} \mathrm{O}_{\text {carb }}$ than the dolostones, with a slightly negative correlation between $\mathrm{Mn} / \mathrm{Sr}$ and $\delta^{18} \mathrm{O}_{\text {carb }}$ (Fig. 7b), probably indicating alteration by meteoric fluids. However, their $\delta^{13} \mathrm{C}_{\text {carb }}$ values resemble those of the dolostones, arguing against significant resetting of the $\mathrm{C}$ isotopes. The similarities of the cherty dolostones and dolostones in $\delta^{13} \mathrm{C}_{\text {carb }}, \delta^{18} \mathrm{O}_{\text {carb }}$ and $\mathrm{Mn} / \mathrm{Sr}$ ratios imply that silicification did not alter the C-O isotope systematics and elemental concentration with exception of increasing Si content. This is consistent with field observations that chert layers generally follow the primary sedimentary laminae (Fig. 3j), as a result of silicification at very early diagenetic stage.

Although care was taken during sample preparation for the bulk-rock C-O isotope analyses, it is impossible to completely avoid small secondary veinlets or fractures that might be related to secondary alteration. The close agreement between $\delta^{13} \mathrm{C}$ data obtained from bulk-rock powders and micro-drilled samples (Fig. 6A), however, documents that influence by secondary processes is insignificant.

Good preservation of C-O isotope systematics in the Hutuo carbonates is not surprising because these rocks have undergone only lower greenschist facies metamorphism which is consistent with the well preserved sedimentary structures and microstructures. In summary, most of the Hutuo carbonates retain their original $\delta^{13} \mathrm{C}$ signal and can be used to document the carbon 
cycles in the Hutuo Basin.

\section{$5.2 \delta^{13} \mathrm{C}$ trend of the Hutuo Group}

A three-stage evolutionary curve and a general tendency toward lower $\delta^{13} \mathrm{C}_{\text {carb }}$ values can be observed in the Hutuo carbonates which is ca. $5000 \mathrm{~m}$ in thickness (Fig. 5 and 6). This starts with exclusively positive $\delta^{13} \mathrm{C}_{\text {carb }}(+1.3$ to $+3.4 \%$ ) in the lower carbonate members of the Dashiling and Qingshicun Formations (stage A), followed by a transition from positive values to oscillating positive and negative values in $\sim 2500 \mathrm{~m}$ thick carbonates of the Wenshan, Hebiancun, Jianancun and Daguandong Formations (stage B). The trend ends with exclusively negative $\delta^{13} \mathrm{C}$ preserved in $>500$ m thick dolostones of the Huaiyincun and Beidaxing Formations (stage C). The $\delta^{13} \mathrm{C}_{\text {carb }}$ curve is generally consistent with previously published data (Kong et al., 2011; Zhong and Ma, 1997). Zhong and Ma (1997) noted the abrupt changes of $\delta^{13} \mathrm{C}_{\text {carb }}$ near the Jianancun/Daguandong and Daguandong/Huaiyincun boundaries respectively, with the latter being also observed in this study. These were considered to reflect changes in the burial rate of organic carbon. Kong et al (2011) observed a decrease in $\delta^{13} \mathrm{C}_{\text {carb }}$ values from the Wenshan Formation to the middle Daguandong Formation and a pronounced negative $\delta^{13} \mathrm{C}_{\text {carb }}$ excursion at the boundary between the Daguandong and Huaiyincun Formations, which are interpreted by the authors as the response to global glaciations in the Paleoproterozoic. This interpretation, however, is based on a problematic chronological framework that has placed the Hutuo Group between 2.5 and 2.2 Ga. Available geochronological data have constrained the depositional age of the Hutuo Group to between 2.14 Ga and 1.83 Ga (Fig. 2, Guo et al., 2011; Du et al., 2010), with the thick carbonate successions largely younger than $2.09 \mathrm{Ga}$ and significantly postdating the 2.4-2.3 Ga Huronian glaciations (Hoffman, 2013, and references therein).

The $\delta^{13} \mathrm{C}_{\text {carb }}$ values of the Hutuo carbonates recorded changes in the marine carbon cycle during the late Paleoproterozoic. It is generally assumed that an increase or decrease in the burial rate of the ${ }^{12} \mathrm{C}$-enriched organic carbon leads to a heavier or lighter isotopic composition of the DIC (dissolved inorganic carbon) reservoir, and of the resulting carbonate precipitates. The persistent positive $\delta^{13} \mathrm{C}_{\text {carb }}$ values in the lower Hutuo Group might reflect an increase in organic carbon burial related to high primary productivity, although increased weathering rates, as 
1 indicated by the rise in ${ }^{87} \mathrm{Sr} /{ }^{86} \mathrm{Sr}$ of carbonates from 0.7022 to 0.7046 between 2.5 and 1.9 Ga,

2 might also have been a major factor (Papineau, 2010 and references therein). This interval covers

3 at least $300 \mathrm{~m}$ and possibly up to $1500 \mathrm{~m}$ of the lowermost carbonate units of the Hutuo Group

4 (Fig. 5), which is characterized by orange-colored massive or stromatolitic dolostones almost devoid of organic matter. The lacking of organic-rich sedimentary rocks during this period remains to be elucidated and is consistent with general absence of organic-rich sedimentary rocks deposited during the LJE, but more common afterwards (Papineau et al., 2013; Melezhik et al., 1999b). The negative $\delta^{13} \mathrm{C}_{\text {carb }}$ values in the Huaiyincun Formation have been related to the decline of stromatolites (Zhong and Ma, 1997), although this coincidence does not necessarily support their genetic relations. Alternatively the negative $\delta^{13} \mathrm{C}_{\text {carb }}$ values, along with the general trend of the decrease in $\delta^{13} \mathrm{C}_{\text {carb }}$ from the Doucun to the Dongye Subgroups (Fig. 6), could have resulted from the oxidation (remineralization) of organic carbon produced during the preceding positive $\delta^{13} \mathrm{C}_{\text {carb }}$ excursions. Massive accumulation of oxygen in the atmosphere and the shallow ocean resulted from enhanced organic carbon burial during the LJE might have triggered oxidative recycling of a fraction of the organic matter previously sequestered, i.e., the SFE (Kump et al., 2011). The shift from oscillating positive and negative $\delta^{13} \mathrm{C}_{\text {carb }}$ values in the Wenshan, Hebiancun, Jianancun and Daguandong Formations to exclusively negative $\delta^{13} \mathrm{C}$ probably recorded fluctuations in the redox states and the gradual oxygenation of the shallow ocean.

\subsection{Termination and the aftermath of the LJE in the NCC}

Numerous studies have shown that unprecedented positive $\delta^{13} \mathrm{C}_{\text {carb }}$ excursions (generally $>5 \%$ ) in marine carbonates, i.e., the LJE, have been recorded in 2.2-2.06 Ga successions in all continents except Antarctica (Tang et al., 2011; Maheshwari et al., 2010; Bekker et al., 2006; Melezhik and Fallick, 1996; Schidlowski et al., 1976). The heaviest $\delta^{13} \mathrm{C}_{\text {carb }}$ found in the Hutuo Group, however, are those from the lowermost part of the carbonate succession (the Dashiling Formation) which yielded $\delta^{13} \mathrm{C}_{\text {carb }} \leq+3.4 \%$. This is consistent with two previous studies that

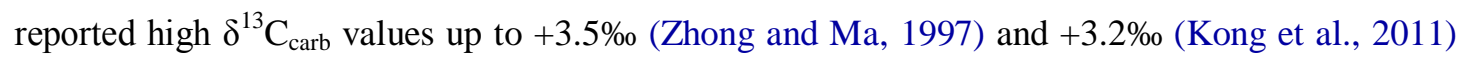
from the same member. Given the significant sedimentary hiatus between the Wutai Group greenstones ( $2.5 \mathrm{Ga}$ ) and the Hutuo Group $\_2.14 \mathrm{Ga}$ ), it can be expected that much of the LJE, 
1 particularly those extremely positive $\delta^{13} \mathrm{C}_{\text {carb }}$ signals, was not recorded in the Hutuo carbonates. Instead, those slightly positive $\delta^{13} \mathrm{C}_{\text {carb }}$ values (+1.3 to $+3.4 \%$ ) preserved in the Dashiling Formation likely correspond to the "tail" of the LJE, because $\delta^{13} \mathrm{C}$ values of the overlying carbonates never exceed $+3.0 \%$ and show a general decreasing trend superimposed with variations from slightly positive to negative values. $\delta^{13} \mathrm{C}_{\text {carb }}$ values lower than $+3.0 \%$ in the carbonates overlying those with $\delta^{13} \mathrm{C}_{\mathrm{carb}}>+5 \%$ o has been used to mark the ending of the LJE (Martin et al., 2013a, and references therein). Detailed geochronological studies showed that termination of the LJE is largely synchronous in many successions investigated (Martin et al., 2013a, b), including the North Transfennoscandian Greenstone Belt (2056.6 $\pm 0.8 \mathrm{Ma})$ and the Peräphoja Schist Belt (2050 $\pm 8 \mathrm{Ma})$ in Fennoscandia and the Transvaal Supergroup in South Africa (2054 $\pm 2 \mathrm{Ma}$ ) (Martin et al., 2013b). If the transition of $\delta^{13} \mathrm{C}_{\mathrm{carb}}$ from persistent positive values in the lower Hutuo Group to oscillating positive and negative values in the overlying carbonates marks the end of the LJE in the NCC, the latter can be constrained to $<2.09$ Ga and possibly around $2.06 \mathrm{Ga}$ in age.

Recent investigations on Paleoproterozoic carbonate successions elsewhere in the NCC have yielded $\delta^{13} \mathrm{C}_{\text {carb }}$ values up to $+5.9 \%$ from the 2.24-2.02 Ga Liaohe Group (Tang et al., 2011) and +4.0\% from the Songshan Group (Lai et al., 2012) which has a poorly constrained depositional age between 2.35 and $1.78 \mathrm{Ga}$ (Liu et al., 2012). Although their depositional ages are roughly similar to that of the Hutuo Group according to available age dates, their slightly higher $\delta^{13} \mathrm{C}_{\text {carb }}$ values may suggest lower stratigraphic positions if the Paleoproterozoic carbon isotope excursions can be strictly correlated across all continents. Nevertheless, available data indicates that extremely positive $\delta^{13} \mathrm{C}_{\text {carb }}$ excursions might have not been preserved in the NCC due to significant sedimentary hiatus.

It should be noted that a fourth stage of the carbon isotope curve characterized by persistent near-zero $\delta^{13} \mathrm{C}_{\text {carb }}$ values appears to be present in the $\sim 1500$ m-thick Beidaxing Formation near top of the Hutuo carbonate successions (Zhong and Ma, 1997), similar to those of late Paleoproterozoic and Mesoproterozoic carbonates in the NCC (e.g., Luo et al., 2014; Guo et al., 2013). This period of stable $\delta^{13} \mathrm{C}_{\text {carb }}$ values probably marks the final return to normal carbon cycle. However, because of the lack of carbonate in the uppermost Guojiazhai Subgroup, it remains unclear whether this state of normal carbon cycle extends to the "Boring Billion" (Brasier and 
Lindsay, 1998) or is followed by additional smaller perturbations.

\section{Conclusions}

The $>10$ km-thick volcano-sedimentary sequence of the 2.14-1.83 Ga Hutuo Group preserves a wealth of sedimentology, petrology and geochemistry of the termination and aftermath of the LJE. The carbonates in the Hutuo Group were largely deposited in supra-tidal to sub-tidal environments during the formation of a carbonate ramp in a synkinematically opening rift tectonic setting.

The absence of a co-variation between $\delta^{13} \mathrm{C}_{\text {carb }}$ and $\delta^{18} \mathrm{O}_{\text {carb, }}$, the relatively high $\delta^{18} \mathrm{O}_{\text {carb }}$ values and the good agreement between $\delta^{13} \mathrm{C}_{\text {carb }}$ obtained from whole-rock samples and micro-drilled samples (most $\delta^{18} \mathrm{O}_{\text {carb v-SMow }}>20 \%$ ) suggest that the C-O isotopes were not seriously affected by post-sedimentary processes, although alteration by meteoric fluids probably changed the $\mathrm{Mn} / \mathrm{Sr}$ ratio of some samples.

The Hutuo carbonates display a three-stage evolution in the $\delta^{13} \mathrm{C}_{\text {carb }}$ curve. Carbonates in the Dashiling and Qingshicun Formations yield exclusively positive $\delta^{13} \mathrm{C}_{\text {carb }}$ between +1.3 and + 3.4\%. The overlying 3000 m thick carbonates of the Wenshan, Hebiancun, Jianancun and Daguandong Formations show oscillating positive and negative $\delta^{13} \mathrm{C}_{\text {carb }}$ values ranging between -5.2 and $+2.7 \%$. The trend ends with exclusively negative $\delta^{13} \mathrm{C}_{\text {carb }}$ mostly below $-2 \%$ preserved in $>500 \mathrm{~m}$ thick dolostones of the Huaiyincun and Beidaxing Formations. The first stage likely corresponds to the end of the LJE, whereas the subsequent two stages reflect the aftermath of the LJE and the onset of SFE. The SFE is characterized in part by the massive oxidation of organic matter, which produces negative $\delta^{13} \mathrm{C}_{\text {carb }}$ values, and that was enabled by the prior accumulation of oxygen during the LJE. The new $\delta^{13} \mathrm{C}_{\text {carb }}$ data presented here support that the termination of the LJE probably occurred shortly after $2.09 \mathrm{Ga}$ in the North China Craton, and point to an increased influence of oxygen on the carbon cycle from the Doucun to the Dongye Subgroups.

\section{Acknowledgements}

We would like to acknowledge funding from National Natural Science Foundation of 
China (grants 41272038), Fundamental Research Funds for National Universities, China University of Geosciences (Wuhan), State Key Laboratory of Biogeology and Environmental Geology, China University of Geosciences (No. GKZ14Y660), and the 111 Program for the Ministry of Education of China and the State Administration of Foreign Expert Affairs of China (grant B07039). We thank Wenjing Xu, Jian Gao, Shuzhan Liu, Yantao Zhang, Mingjian Yang, Longfei Ye for their assistance in field work and sample preparation, the two anonymous reviewers for their constructive reviews, and the editor for handling the manuscript.

\section{REFERENCES CITED}

Bai, J., 1986. The early Precambrian geology of Wutaishan. Tianjin Science and Technology Press, Tianjin. 475 (in Chinese with English abstract)

Baker, A.J., Fallick, A.E., 1989a. Evidence from Lewisian limestones for isotopically heavy carbon in two-thousand-million-year-old sea water., 337: 352-354

Baker, A.J., Fallick, A.E., 1989b. Heavy carbon in two-billion-year-old marbles from Lofoten-Vesterälen, Norway: Implications for the Precambrian carbon cycle. Geochimica et Cosmochimica Acta, 53: 1111-1115

Bathurst, R.G., 1972. Carbonate sediments and their diagenesis. Developments in Sedimentology. Elsevier, Amsterdam. 658

Bekker, A., Karhu, J.A., Eriksson, K.A., Kaufman, A.J., 2003. Chemostratigraphy of Paleoproterozoic carbonate successions of the Wyoming Craton: tectonic forcing of biogeochemical change? Precambrian Research, 120: 279-325

Bekker, A., Karhu, J.A., Kaufman, A.J., 2006. Carbon isotope record for the onset of the Lomagundi carbon isotope excursion in the Great Lakes area, North America. Precambrian Research, 148: $145-180$

Bekker, A., Kaufman, A.J., Karhu, J.A., Eriksson, K.A., 2005. Evidence for Paleoproterozoic cap carbonates in North America. Precambrian Research, 137: 167-206

Bickle, M.J., Chapman, H.J., Ferry, J.M., Rumble, D., Fallick, A.E., 1997. Fluid Flow and Diffusion in the Waterville Limestone, South-Central Maine: Constraints from Strontium, Oxygen and Carbon Isotope Profiles. Journal of Petrology, 38: 1489-1512

Bickle, M.J., Chapman, H.J., Wickham, S.M., Peters, M.T., 1995. Strontium and oxygen isotope profiles across marble-silicate contacts, Lizzies Basin, East Humboldt Range, Nevada: constraints on metamorphic permeability contrasts and fluid flow. Contributions to Mineralogy and Petrology, 121: 400-413

Boulvais, P., Fourcade, S., Gruau, G., Moine, B., Cuney, M., 1998. Persistence of pre-metamorphic C and $\mathrm{O}$ isotopic signatures in marbles subject to Pan-African granulite-facies metamorphism and U-Th mineralization (Tranomaro, Southeast Madagascar). Chemical Geology, 150: 247-262

Brasier, M.D., Lindsay, J.F., 1998. A billion years of environmental stability and the emergence of eukaryotes: New data from northern Australia. Geology, 26: 555 -558

Deer, W.A., Howie, R.A., Zussman, J., 1992. An Introduction to the Rock-forming Minerals (Second 
edition). Longman, London. 696

Dongye, M., 1989. The early-middle Precambrian phosphate deposits in North China. Journal of Changchun University of Earth Science, 19: 181-186 (in Chinese with English abstract)

Du, L., Yang, C., Guo, J., Wang, W., Ren, L., Wan, Y., Geng, Y., 2010. The age of the base of the Paleoproterozoic Hutuo Group in the Wutai Mountains area, North China Craton: SHRIMP zircon U-Pb dating of basaltic andesite. Chinese Science Bulletin, 55: 1782-1789

Du, L., Yang, C., Wang, W., Ren, L., Wan, Y., Song, H., Geng, Y., Hou, K., 2011. The re-examination of the age and stratigraphic subdivision of the Hutuo Group in the Wutai Mountains area, North China Craton: Evidences from geology and zircon U-Pb geochronology. Acta Petrologica Sinica, 27: 1037-1055

Du, L., Yang, C., Wang, W., Ren, L., Wan, Y., Wu, J., Zhao, L., Song, H., Geng, Y., Hou, K., 2013. Paleoproterozoic rifting of the North China Craton: Geochemical and zircon Hf isotopic evidence from the 2137 Ma Huangjinshan A-type granite porphyry in the Wutai area. Journal of Asian Earth Sciences, 72: 190-202

Du, L.L., Yang, C.H., Ren, L.D., Wan, Y.S., Wu, J.S., 2009. Petrology, geochemistry and petrogenesis of the metabasalts of the Hutuo Group, Wutai Mountains, Shanxi, China. Geological Bulletin of China, 28: 867-876

Emrich, K., Ehhalt, D.H., Vogel, J.C., 1970. Carbon isotope fractionation during the precipitation of calcium carbonate. Earth and Planetary Science Letters, 8: 363-371

Gaucher, C., Sial, A.N., Ferreira, V.P., Pimentel, M.M., Chiglino, L., Sprechmann, P., 2007. Chemostratigraphy of the Cerro Victoria Formation (Lower Cambrian, Uruguay): evidence for progressive climate stabilization across the Precambrian-Cambrian boundary. Chemical Geology, 237: $28-46$

Guerrera, A., Peacock, S.M., Knauth, L.P., 1997. Large ${ }^{18} \mathrm{O}$ and ${ }^{13} \mathrm{C}$ depletions in greenschist facies carbonate rocks, western Arizona. Geology, 25: 943-946

Guo, H., Du, Y., Kah, L.C., Huang, J., Hu, C., Huang, H., Yu, W., 2013. Isotopic composition of organic and inorganic carbon from the Mesoproterozoic Jixian Group, North China: Implications for biological and oceanic evolution. Precambrian Research, 224: 169-183

Guo, J., Ren, L., Bai, J., 2011. Analysis of the sedimentary setting of the Paleoproterozoic Hutuo Group in the Wutaishan area: Foreland basin or intracontinental rift basin? Earth Science Frontiers, 18: $211-220$

Hoffman, P.F., 2013. The Great Oxidation and a Siderian snowball Earth: MIF-S based correlation of Paleoproterozoic glacial epochs. Chemical Geology, 362: 143-156

Hou, G., Li, J., Liu, Y., Qian, X., 2005. Late paleoproterozoic extensional events in North China Craton: Aulacogen and dyke swarms. Progress in Natural Science, 15: 1366-1373 (in Chinese)

Hudson, J.D., 1977. Stable isotopes and limestone lithification. Journal of the Geological Society, 133: 637-660

Jacobsen, S.B., Kaufman, A.J., 1999. The Sr, C and O isotopic evolution of Neoproterozoic seawater. Chemical Geology, 161: 37-57

Kah, L.C., Sherman, A.G., Narbonne, G.M., Knoll, A.H., Kaufman, A.J., 1999. $\delta^{13}$ C stratigraphy of the Proterozoic Bylot Supergroup, Baffin Island, Canada: implications for regional lithostratigraphic correlations. Canadian Journal of Earth Sciences, 36: 313-332

Karhu, J.A., Holland, H.D., 1996. Carbon isotopes and the rise of atmospheric oxygen. Geology, 24: $867-870$ 
Kaufman, A.J., Knoll, A.H., 1995. Neoproterozoic variations in the C-isotopic composition of seawater: stratigraphic and biogeochemical implications. Precambrian Research, 73: 27-49

Kong, F., Yuan, X., Zhou, C., 2011. Paleoproterozoic glaciation: Evidence from carbon isotope record of the Hutuo Group, Wutai Mountain area of Shanxi Province, China. Chinese Science Bulletin, 56: 2922-2930

Kump, L.R., Junium, C., Arthur, M.A., Brasier, A., Fallick, A., Melezhik, V., Lepland, A., CČrne, A.E., Luo, G., 2011. Isotopic evidence for massive oxidation of organic matter following the Great Oxidation Event. Science, 334: 1694-1696

Kusky, T.M., Li, J., 2003. Paleoproterozoic tectonic evolution of the North China Craton. Journal of Asian Earth Sciences, 22: 383-397

Lai, Y., Chen, C., Tang, H., 2012. Paleoproterozoic Positive $\delta^{13} \mathrm{C}$ Excursion in Henan, China. Geomicrobiology Journal, 29: 287-298

Lewis, S., Holness, M., Graham, C., 1998. Ion microprobe study of marble from Naxos, Greece: grain-scale fluid pathways and stable isotope equilibration during metamorphism. Geology, 26: 935-938

Liu, C., Zhao, G., Sun, M., Zhang, J., He, Y., Yin, C., Wu, F., Yang, J., 2011. U-Pb and Hf isotopic study of detrital zircons from the Hutuo group in the Trans-North China Orogen and tectonic implications. Gondwana Research, 20: 106-121

Liu, C., Zhao, G., Sun, M., Zhang, J., Yin, C., He, Y., 2012. Detrital zircon U-Pb dating, Hf isotopes and whole-rock geochemistry from the Songshan Group in the Dengfeng Complex: constraints on the tectonic evolution of the Trans-North China Orogen. Precambrian Research, 192: 1-15

Luo, G., Junium, C.K., Kump, L.R., Huang, J., Li, C., Feng, Q., Shi, X., Bai, X., Xie, S., 2014. Shallow stratification prevailed for $\sim 1700$ to $\sim 1300$ Ma ocean: Evidence from organic carbon isotopes in the North China Craton. Earth and Planetary Science Letters, 400: 219-232

Maheshwari, A., Sial, A.N., Gaucher, C., Bossi, J., Bekker, A., Ferreira, V.P., Romano, A.W., 2010. Global nature of the Paleoproterozoic Lomagundi carbon isotope excursion: A review of occurrences in Brazil, India, and Uruguay. Precambrian Research, 182: 274-299

Martin, A.P., Condon, D.J., Prave, A.R., Lepland, A., 2013a. A review of temporal constraints for the Palaeoproterozoic large, positive carbonate carbon isotope excursion (the Lomagundi-Jatuli Event). Earth-Science Reviews, 127: 242-261

Martin, A.P., Condon, D.J., Prave, A.R., Melezhik, V.A., Lepland, A., Fallick, A.E., 2013b. Dating the termination of the Palaeoproterozoic Lomagundi-Jatuli carbon isotopic event in the North Transfennoscandian Greenstone Belt. Precambrian Research, 224: 160-168

Melezhik, V., Fallick, A.E., Pokrovsky, B.G., 2005b. Enigmatic nature of thick sedimentary carbonates depleted in ${ }^{13} \mathrm{C}$ beyond the canonical mantle value: the challenges to our understanding of the terrestrial carbon cycle. Precambrian Research, 137: 131-165

Melezhik, V., Prave, A., Fallick, A., Hanski, E., Lepland, A., Kump, L., Strauss, H., 2013. Reading the Archive of Earth's Oxygenation: Volume 1: The Palaeoproterozoic of Fennoscandia as Context for the Fennoscandian Arctic Russia. Springer, Heidelberg. 490

Melezhik, V.A., Fallick, A.E., 1996. A widespread positive $\delta^{13} C_{\text {carb }}$ anomaly at around 2.33-2.06 Ga on the Fennoscandian Shield: a paradox? Terra Nova, 8: 141-157

Melezhik, V.A., Fallick, A.E., 2003. $\delta^{13} \mathrm{C}$ and $\delta^{18} \mathrm{O}$ variations in primary and secondary carbonate phases: several contrasting examples from Palaeoproterozoic ${ }^{13} \mathrm{C}$-rich metamorphosed dolostones. Chemical Geology, 201: 213-228 
Melezhik, V.A., Fallick, A.E., 2010. On the Lomagundi-Jatuli carbon isotopic event: The evidence from the Kalix Greenstone Belt, Sweden. Precambrian Research, 179: 165-190

Melezhik, V.A., Fallick, A.E., Filippov, M.M., Larsen, O., 1999a. Karelian shungite - an indication of 2.0-Ga-old metamorphosed oil-shale and generation of petroleum: geology, lithology and geochemistry. Earth-Science Reviews, 47: 1-40

Melezhik, V.A., Fallick, A.E., Medvedev, P.V., Makarikhin, V.V., 1999b. Extreme ${ }^{13} \mathrm{C}_{\text {carb }}$ enrichment in ca. 2.0 Ga magnesite-stromatolite-dolomite-'red beds' association in a global context: a case for the world-wide signal enhanced by a local environment. Earth-Science Reviews, 48: 71-120

Melezhik, V.A., Fallick, A.E., Rychanchik, D.V., Kuznetsov, A.B., 2005a. Palaeoproterozoic evaporites in Fennoscandia: implications for seawater sulphate, the rise of atmospheric oxygen and local amplification of the $\delta^{13} \mathrm{C}$ excursion. Terra Nova, 17: 141-148

Melezhik, V.A., Gorokhov, I.M., Fallick, A.E., Gjelle, S., 2001. Strontium and carbon isotope geochemistry applied to dating of carbonate sedimentation: an example from high-grade rocks of the Norwegian Caledonides. Precambrian Research, 108: 267-292

Miao, P.S., Zhang, Z.F., Zhang, J.Z., Zhao, Z.X., Xu, S.C., 1999. Paleoproterozoic stratigraphic sequence in the Wutai Mountain area. Regional Geology of China, 18: 405-413 (in Chinese with English abstract)

Nafi, M., Fei, Q., Yang, X.H., 2004. Type of Sandstone and Source of Carbonate Cement in the Kongdian Formation (Upper Part), South Slope of the Dongying Depression, East China. Journal of Applied Sciences, 4: 235-241

Papineau, D., 2010. Global biogeochemical changes at both ends of the Proterozoic: insights from phosphorites. Astrobiology, 10: 165-181

Papineau, D., De Gregorio, B.T., Stroud, R.M., Steele, A., Pecoits, E., Konhauser, K., Wang, J.H., Fogel, M.L., 2010. Ancient graphite in the Eoarchean quartz-pyroxene rocks from Akilia in southern West Greenland II: Isotopic and chemical compositions and comparison with Paleoproterozoic banded iron formations. Geochimica et Cosmochimica Acta, 74: 5884-5905

Papineau, D., Purohit, R., Fogel, M.L., Shields-Zhou, G.A., 2013. High phosphate availability as a possible cause for massive cyanobacterial production of oxygen in the Paleoproterozoic atmosphere. Earth and Planetary Science Letters, 362: 225-236

Schidlowski, M., Eichmann, R., Junge, C.E., 1976. Carbon isotope geochemistry of the Precambrian Lomagundi carbonate province, Rhodesia. Geochimica et Cosmochimica Acta, 40: 449-455

Tang, H., Chen, Y., Wu, G., Lai, Y., 2011. Paleoproterozoic positive $\delta^{13} \mathrm{C}_{\text {carb }}$ excursion in the northeastern Sino-Korean craton: Evidence of the Lomagundi Event. Gondwana Research, 19: 471-481

Valley, J.W., 1986. Stable isotope geochemistry of metamorphic rocks, Stable Isotopes in High Temperature Geological Processes. Reviews in Mineralogy and Geochemistry. Mineralogical Society of America. 445-489

Veizer, J., 1983. Chemical diagenesis of carbonates: theory and application of trace element technique. Stable Isotopes in Sedimentary Geology. SEPM Short Course No. 10. Society for Sedimentary Geology, Dallas

Wan, Y., Miao, P., Liu, D., Yang, C., Wang, W., Wang, H., Wang, Z., Dong, C., Du, L., Zhou, H., 2010. Formation ages and source regions of the Palaeoproterozoic Gaofan, Hutuo and Dongjiao groups in the Wutai and Dongjiao areas of the North China Craton from SHRIMP U-Pb dating of detrital zircons: Resolution of debates over their stratigraphic relationships. Chinese Science 
Wang, R., 1997. A primary discussion on Rb-Sr and Sm-Nd isotopic systems of basaltic rocks of Hutuo Group of early Proterozoic, Shanxi. Progress in Precambrian Research, 20: 35-42 (in Chinese with English abstract)

Wilde, S.A., Zhao, G., Wang, K., Sun, M., 2004. First SHRIMP zircon U-Pb ages for Hutuo Group in Wutaishan: further evidence for Palaeoproterozoic amalgamation of North China Craton. Chinese Science Bulletin, 49: 83-90 (in Chinese)

Wu, J., Liu, D., Jin, L., 1986. The zircon U-Pb age of metamorphosed basic volcanic lavas from the Hutuo Group in the Wutai Mountain area, Shanxi Province. Geological Review, 32: 178-185 (in Chinese with English abstract)

Zhao, D., 1982. The age and genesis of phosphorous deposits of the Dongjiao type. Chinese Journal of Geology, (4): 386-394 (in Chinese with English abstract)

Zhao, G., Sun, M., Wilde, S.A., Sanzhong, L., 2005. Late Archean to Paleoproterozoic evolution of the North China Craton: key issues revisited. Precambrian Research, 136: 177-202

Zhao, G., Wilde, S.A., Cawood, P.A., Lu, L., 1999. Tectonothermal history of the basement rocks in the western zone of the North China Craton and its tectonic implications. Tectonophysics, 310: 37-53

Zhong, H., Ma, Y., 1997. Carbon isotope stratigraphy of dolomites in the early Proterozoic succession, north China. Geological Magazine, 134: 763-770

Zhu, S., 1982. An outline of studies on the Precambrian stromatolites of China. Precambrian Research, 18: 367-396

Zhu, S., Chen, H., 1992. Characteristics of Palaeoproterozoic stromatolites in China. Precambrian Research, 57: 135-163 


\section{Figure captions}

Figure 1 (a) Tectonic divisions of the North China Craton highlighting exposed Archean and Paleoproterozoic rocks (modified after Zhao et al., 1999). (b) Simplified geological map of the Wutai area (modified after Bai, 1986).

Figure 2 Generalized stratigraphic column of the Hutuo Group with correlation to Paleoproterozoic successions in N Henan (Lai et al., 2011) and E Liaoning provinces (Tang et al., 2011). Previously published age dates and $C$ isotope data are shown.

Figure 3 Sedimentary structures. (a) Herringbone cross-bedding, Wenshan Fm. (b) Ripple marks, Wenshan Fm. (c) Disturbed beds (black arrows), rounded intraclasts and flat pebbles (white arrows), Hebiancun Fm. (d) Convolute bedding, Qingshicun Fm. (e) Digitate stromatolite, Jianancun Fm. (f) Stromatolite bioherms, Jianancun Fm. (g) Stromatolite bioherms, Dashiling Fm. (h) Purple-colored wavy-Conical stromatolites, Wenshan Fm. (i) Oblique section of tightly-packed stromatolites, Daguandong Fm. (j) Cherty dolostone with alternating purplish chert layers (ch) and white dolomicrite layers (dol) indicating silicification during very early diagenetic stage, Hebiancun Fm. Hammers are $40 \mathrm{~cm}$ long, and marker pen is $14 \mathrm{~cm}$ long.

Figure 4 Petrographic features of the Hutuo carbonates. (a) Slab of an orange-colored massive dolostone micro-drilled for $\mathrm{C}$ isotope analysis, arrow showing the drill pit. (b) Pure microcrystalline dolostone with crystals generally smaller than $15 \mu \mathrm{m}$. (c) Primary laminae in stromatolitic dolostone. (d) Magnified view of (c) showing dolomite microcrystals and clots of carbonaceous material. (e) Alternated dark organic-rich and transparent dolomite laminae in a stromatolite. (f) Magnified view of (e) showing the dark organic-rich layers and clots. Note also the disseminated hematite (Hem) particles and local occurrence of quartz (Qtz).

Figure 5 Stratigraphic variation of $\delta^{13} \mathrm{C}, \delta^{18} \mathrm{O}$ and $\mathrm{Mn} / \mathrm{Sr}$ ratios of the Hutuo Group. Three stages of the $\delta^{13} \mathrm{C}$ curve (A, B and C) are shown in detail in Fig. 6.

Figure $6 \delta^{13} \mathrm{C}$ curves of the lower, middle and upper part of the Hutuo carbonates.

Figure 7 Cross-plots illustrating post-sedimentary alteration of the carbonates. 